\begin{tabular}{|c|l|}
\hline Title & Formation of residual ferrite in 9Cr-ODS ferritic steels \\
\hline Author(s) & Y amamoto, M.; Ukai, S.; Hayashi, S.; Kaito, T.; Ohtsuka, S. \\
\hline Citation & $\begin{array}{l}\text { Materials Science and Engineering: A, 527(16-17), 4418-4423 } \\
\text { https://doi.org/40.1016/.msea.2010.03.079 }\end{array}$ \\
\hline Issue Date & 2010-06-25 \\
\hline Doc URL & http://hdl.handle.net/2115/43186 \\
\hline Type & article(author version) \\
\hline File Information & MSEA 527-16-17_4418-4423.pdf \\
\hline
\end{tabular}

Instructions for use 


\title{
Formation of Residual Ferrite in 9Cr-ODS Ferritic Steels
}

\author{
M. Yamamoto, S. Ukai*, S. Hayashi \\ Hokkaido University, N13, W8, Kita-ku, Sapporo 060-8628, Japan \\ T. Kaito and S. Ohtsuka \\ Japan Atomic Energy Agency, 4002, Narita, Oarai-machi, Ibaraki 311-1393, Japan \\ * Corresponding author, Tel \& Fax: +81-11-706-6355, \\ E-mail: s-ukai@eng.hokudai.ac.jp
}

\begin{abstract}
It is recognized that the high-temperature strength of 9Cr-ODS ferritic steels is maintained by the presence of a ferrite phase. In order to clarify the formation process of the ferrite phase, 9Cr-ODS ferritic steels containing various contents of $\mathrm{Y}_{2} \mathrm{O}_{3}$, i.e., 0 mass $\%, 0.1$ mass $\%, 0.35$ mass $\%$, and 0.7 mass $\%$, are prepared by means of mechanical alloying and hot pressing. The ferrite phase is formed by the addition of 0.35 mass $\%$ and 0.7 mass $\% \mathrm{Y}_{2} \mathrm{O}_{3}$; however, it is not formed for steels without and with 0.1 mass $\% \mathrm{Y}_{2} \mathrm{O}_{3}$ normalized for $1 \mathrm{~h}$ at $1050{ }^{\circ} \mathrm{C}$. It is considered from the thermodynamic analyses that the pinning of the $\alpha-\gamma$ interface motion by the dispersed $\mathrm{Y}-\mathrm{Ti}$ complex oxide particles can be attributed to the retention of the ferrite phase normalized at $1050{ }^{\circ} \mathrm{C}$, and this ferrite phase cannot be $\delta$-ferrite that is in equilibrium with the $\gamma$-phase.
\end{abstract}




\section{Introduction}

Oxide-dispersion-strengthened (ODS) ferritic steels are known to be promising candidates for use as advanced fission and fusion materials that require excellent radiation resistance and high-temperature capabilities [1-3]. We focus on the development of 9Cr-ODS ferritic steels [4-9]; their microstructures can be easily controlled by a reversible martensite phase transformation with a remarkably high driving force of a few hundred megajoules per cubic meter as compared to the driving force of irreversible recrystallization of a few megajoules per cubic meter for 12Cr-ODS ferritic steels [10]. 9Cr-ODS ferritic steel claddings are currently being manufactured for use in fast reactor fuel elements at the Japan Atomic Energy Agency by inducing reversible martensitic and $\alpha / \gamma$ phase transformations.

From a series of extensive experiments, it has been recognized that 9Cr-ODS ferritic steel claddings manufactured in an engineering process exhibit a dual phase structure comprising tempered martensite and ferrite. The high-temperature strength of the manufactured 9Cr-ODS ferritic steel claddings is significantly improved by the presence of the ferrite phase [11-15].

The formation of the ferrite phase in 9Cr-ODS ferritic steel is unusual because under normalizing and air-cooling conditions, only the full martensite phase can be expected in 9Cr ferritic steel without yttria. However, Cayron et al. also reported the presence of ferritic grains during the normalizing heat treatment of 9Cr-ODS Eurofer steel [16]. In this study, in order to elucidate the cause of the formation of the ferrite phase in 9Cr-ODS ferritic steels, mechanically alloyed (MAed) powders with various amounts of yttria were fabricated and hot-pressed in the laboratory. The origin and 
the formation process of the ferrite phase were investigated by X-ray diffraction, dilatometric experiments, and thermodynamic analyses.

\section{Experimental}

Pure elemental powders of iron (99.5 mass\%, 45-100 $\mu \mathrm{m})$, carbon (99.7 mass\%, 5 $\mu \mathrm{m})$, chromium (99.9 mass\%, under $250 \mu \mathrm{m})$, tungsten (99.9 mass\%, 4.5-7.5 $\mu \mathrm{m}$ ), and titanium (99.7 mass\%, under $150 \mu \mathrm{m}$ ) were mechanically alloyed together with $\mathrm{Y}_{2} \mathrm{O}_{3}$ powder (99.9 mass\%, $20 \mathrm{~nm}$ ) for $48 \mathrm{~h}$ in an argon gas atmosphere using a planetary-type ball mill (Fritsch P-6). A pot with a volume of $250 \mathrm{~cm}^{3}$ was rotated at a speed of $420 \mathrm{rpm}$; the pot contained the powders (35 g) and balls (total weight: 350 g); the weight ratio of the balls to the powders was set at 10:1. The chemical composition of the MAed powder produced was $\mathrm{Fe}-9 \mathrm{Cr}-0.13 \mathrm{C}-2 \mathrm{~W}-0.2 \mathrm{Ti}-0.35 \mathrm{Y}_{2} \mathrm{O}_{3}$ (mass\%). The excess oxygen (Ex. O) was measured to be 0.09 mass\%, which was determined by subtracting the amount of oxygen contained in $\mathrm{Y}_{2} \mathrm{O}_{3}$ from the total oxygen content; this amount of oxygen is sufficient for the formation of a Y-Ti complex oxide. Specimens containing 0.1 mass $\%$ and 0.7 mass $\% \mathrm{Y}_{2} \mathrm{O}_{3}$ and without $\mathrm{Y}_{2} \mathrm{O}_{3}$ were also prepared in an identical manner, and the compositions of $\mathrm{Cr}, \mathrm{C}, \mathrm{W}$, and Ti were unchanged.

The MAed powder was sealed in quartz glasses under vacuum and normalized at $1050{ }^{\circ} \mathrm{C}$ for $1 \mathrm{~h}$; this was followed by quenching in water. The microstructure of the MAed powders was observed using the secondary electron microscope (SEM) of JEOL JSM-6390 after polishing and etching with 50\% dilute aqua regia containing hydrochloric acid and nitric acid in the ratio of 3:1. High-temperature X-ray 
diffraction measurement was conducted at $950{ }^{\circ} \mathrm{C}$ using Philips $\mathrm{X}$ 'Part Pro, which is equipped with a Mo X-ray source and a sample stage made of Pt that facilitates direct electrical heating. The bulk samples with a dimension of $3 \mathrm{~mm} \times 3 \mathrm{~mm} \times 10 \mathrm{~mm}$ were prepared by hot-pressing the MAed powders at $55 \mathrm{MPa}$ and $1100{ }^{\circ} \mathrm{C}$ for $3 \mathrm{~h}$, and their bulk density was measured to be $7.52 \mathrm{~g} / \mathrm{cm}^{3}$. The dilatometric measurement was performed using hot-pressed specimens by Rigaku TMA-8140C during heating at a rate of $0.33^{\circ} \mathrm{C} / \mathrm{s}$.

The computation of the phase diagram and the thermodynamic analyses of the Fe-9Cr-0.13C-2W-0.2Ti system were performed using the Thermo-Calc code and the TCFE6 database, and the Gibbs energy difference between ferrite $(\alpha)$ and austenite $(\gamma)$ was considered for predicting the driving force for the reverse transformation of the $\alpha$-phase to the $\gamma$-phase.

\section{Results}

The computed phase diagram of the Fe-9Cr-0.13C-2W-0.2Ti system without $\mathrm{Y}_{2} \mathrm{O}_{3}$ is shown in Fig. 1 with respect to the carbon content. For a carbon content of 0.13 mass $\%$, the single austenite $\gamma$-phase containing $\mathrm{TiC}$ carbide exists at the normalizing temperature of $1050{ }^{\circ} \mathrm{C}$. The equilibrium $\gamma / \gamma+\delta$ phase boundary at this temperature corresponds to a carbon content of 0.08 mass $\%$, beyond which $\delta$-ferrite is not stable.

Fig. 2 shows SEM micrographs of the MAed powders for specimens with 0.1 mass $\%, 0.35$ mass $\%$, and 0.7 mass $\% \mathrm{Y}_{2} \mathrm{O}_{3}$ and without $\mathrm{Y}_{2} \mathrm{O}_{3}$ that were heat-treated by normalizing at $1050{ }^{\circ} \mathrm{C}$ and quenching in water after mechanical alloying. The 
specimens without and with 0.1 mass $\% \mathrm{Y}_{2} \mathrm{O}_{3}$ have the full martensite structure, which was obtained by inducing the transformation from the $\gamma$-phase by water quenching. This result is completely consistent with the computed phase diagram shown in Fig. 1. Nevertheless, the specimens with 0.35 mass $\%$ and 0.7 mass $\% \mathrm{Y}_{2} \mathrm{O}_{3}$ exhibit a dual phase comprising martensite and uniform contrast phases. Digital image analyses showed that the area fraction of the uniform contrast phase was approximately 0.2 for specimens with 0.35 mass $\%$ and 0.7 mass $\% \mathrm{Y}_{2} \mathrm{O}_{3}$. No obvious difference was observed between X-ray diffraction peaks of the martensite phase and uniform contrast phases at room temperature. However, high-temperature X-ray diffraction measurement at $950{ }^{\circ} \mathrm{C}$ showed a considerable difference, as shown in Fig. 3; the specimen without $\mathrm{Y}_{2} \mathrm{O}_{3}$ had diffraction peaks corresponding only to the austenite $\gamma$-phase, whereas specimens with 0.35 mass $\%$ and 0.7 mass $\% \mathrm{Y}_{2} \mathrm{O}_{3}$ had diffraction peaks corresponding to the austenite $\gamma$-phase and the ferrite phase. The austenite $\gamma$-phase transformed to the martensite phase, but the ferrite phase remained unchanged by water quenching. These results prove that the uniform contrast phase is composed of ferrite. Considering that the ferrite phase is formed only in the specimens containing 0.35 mass $\%$ and 0.7 mass $\% \mathrm{Y}_{2} \mathrm{O}_{3}$ and that four types of ODS steels shown in Fig. 2 have an identical chemical composition except for $\mathrm{Y}_{2} \mathrm{O}_{3}$ content, it seems that the presence of a $\mathrm{Y}_{2} \mathrm{O}_{3}$ particle favors the retention of the ferrite phase at $950{ }^{\circ} \mathrm{C}$ (Fig. 3) and $1050{ }^{\circ} \mathrm{C}$ (Fig. 2), which leads to inconsistency with the computed phase diagram shown in Fig. 1.

Dilatometric measurement was carried out from room temperature to $1200{ }^{\circ} \mathrm{C}$ with a heating rate and a cooling rate of $5{ }^{\circ} \mathrm{C} / \mathrm{min}$. Fig. 4 shows the results of the 
dilatometric measurement when $\mathrm{Fe}-9 \mathrm{Cr}-0.13 \mathrm{C}-2 \mathrm{~W}-0.2 \mathrm{Ti}$ was heated without and with 0.35 mass $\% \mathrm{Y}_{2} \mathrm{O}_{3}$. In the case of the specimen without $\mathrm{Y}_{2} \mathrm{O}_{3}$, the linear thermal expansion coefficients started decreasing from $\mathrm{A}_{\mathrm{C} 1}$ point of $850{ }^{\circ} \mathrm{C}$ to $\mathrm{A}_{\mathrm{C} 3}$ point of $880{ }^{\circ} \mathrm{C}$ because of the reverse transformation of the martensite-phase to the $\gamma$-phase, which was in reasonably good agreement with the computed phase diagram shown in Fig. 1. The addition of 0.35 mass $\% \mathrm{Y}_{2} \mathrm{O}_{3}$ induced an increase of up to the $\mathrm{A}_{\mathrm{C} 3}$ point of $930{ }^{\circ} \mathrm{C}$. By comparing both the curves, we found that the specimen with 0.35 mass $\% \mathrm{Y}_{2} \mathrm{O}_{3}$ exhibited a smaller amount of reduction in the linear thermal expansion during the reverse transformation of the martensite-phase to the $\gamma$-phase; this observation indicates that the entire martensite-phase could not be transformed to the $\gamma$-phase. The untransformed ferrite phase corresponds to the X-ray diffraction peaks observed in the specimen with 0.35 mass $\% \mathrm{Y}_{2} \mathrm{O}_{3}$ at $950{ }^{\circ} \mathrm{C}$ (Fig. 3).

The linear thermal expansion coefficients between $1,000{ }^{\circ} \mathrm{C}$ and $1,200{ }^{\circ} \mathrm{C}$ were determined by calculating the thermal expansion differences at temperature intervals of $5{ }^{\circ} \mathrm{C}$; the values obtained are presented in Fig. $5 . \quad$ In this temperature range, the linear thermal expansion coefficient of the specimens without $\mathrm{Y}_{2} \mathrm{O}_{3}$ was constant at $22 \times$ $10^{-6}{ }^{\circ} \mathrm{C}^{-1}$; this value coincides with that of the austenite $\gamma$-phase. Similarly, the linear thermal expansion coefficient of the specimen with 0.35 mass $\% \mathrm{Y}_{2} \mathrm{O}_{3}$ was almost constant at around $19 \times 10^{-6}{ }^{\circ} \mathrm{C}^{-1}$ in this temperature range. The error band of the data was estimated to be about $\pm 1 \times 10^{-6}{ }^{\circ} \mathrm{C}^{-1}$. From equation (1), we could calculate the linear thermal expansion coefficient ( $\alpha_{\mathrm{ODS}}$ ) of the specimen with 0.35 mass $\% \mathrm{Y}_{2} \mathrm{O}_{3}$ by considering the linear fraction of ferrite $\left(\mathrm{f}_{\alpha}\right)$ and linear thermal expansion coefficient of ferrite $\left(\alpha_{F}\right)$ and austenite $\left(\alpha_{A}\right)$ : 


$$
\alpha_{\mathrm{ODS}}=\mathrm{f}_{\alpha} \times \alpha_{\mathrm{F}}+\left(1-\mathrm{f}_{\alpha}\right) \times \alpha_{\mathrm{A}}
$$

where $\alpha_{\mathrm{A}}$ and $\alpha_{\mathrm{F}}$ are $22 \times 10^{-6}{ }^{\circ} \mathrm{C}^{-1}$ and $14 \times 10^{-6}{ }^{\circ} \mathrm{C}^{-1}$, respectively [17]. The value of the linear fraction of ferrite, $\mathrm{f}_{\alpha}$, was obtained by using the following relation:

$$
\begin{aligned}
\mathrm{f}_{\alpha} & =\sqrt{0.2} /(\sqrt{0.2}+\sqrt{0.8}), \\
& =0.33
\end{aligned}
$$

where the numbers 0.2 and 0.8 correspond to the area fraction of the ferrite and austenite, which were obtained by the SEM observation as shown previously. When these values were substituted into equation (1), the resultant value of $\alpha_{\text {ODs }}$ obtained was $19.4 \times 10^{-6}{ }^{\circ} \mathrm{C}^{-1}$; which is represented by a broken straight line in Fig. 5 . This computed value roughly agreed with the result of the dilatometric measurement of the 0.35 mass $\% \mathrm{Y}_{2} \mathrm{O}_{3}$ specimen.

If the untransformed ferrite would correspond to a $\delta$-ferrite in equilibrium with the $\gamma$-phase, its linear thermal expansion coefficient between $1,000{ }^{\circ} \mathrm{C}$ and $1,200{ }^{\circ} \mathrm{C}$ can be estimated by the lever rule of the computed phase diagram. The volume fraction of the $\delta$-ferrite could be converted from the area fraction by the following relation, assuming that the untransformed ferrite belonged to $\delta$-ferrite:

$$
\begin{aligned}
\mathrm{F}_{\delta} & =0.2^{1.5} /\left(0.2^{1.5}+0.8^{1.5}\right), \\
& =0.11,
\end{aligned}
$$

where the volume fraction of $\delta$-ferrite is denoted as $F_{\delta}$. Setting $F_{\delta}$ with 0.11 at $1,050{ }^{\circ} \mathrm{C}$, we estimated the ratio of $\mathrm{F}_{\delta}$ to the volume fraction of the $\gamma$-phase, $\mathrm{F}_{\gamma}$ at a temperature between $1,000{ }^{\circ} \mathrm{C}$ and $1,200{ }^{\circ} \mathrm{C}$, according to the lever rule between $\delta$-ferrite and the $\gamma$-phase. The results are shown in Fig. 6, where the $F_{\delta}$ increased with an increase in temperature. The estimated $\mathrm{F}_{\delta}$ was converted to the linear fraction $\mathrm{f}_{\delta}$, 
and the trend of linear thermal expansion coefficient could be derived according to equation (1). As shown by the broken thin curve in Fig. 5, the thermal expansion coefficient decreased slightly with an increase in temperature. On the other hand, if the ferrite phase is not $\delta$-ferrite, but the untransformed residual ferrite in a non-equilibrium state, the lever rule cannot be satisfied. The volume fraction of the untransformed residual ferrite should be constant even when the temperature increased to up to $1,180{ }^{\circ} \mathrm{C}$, where the $\gamma$-phase decomposed into the $\gamma+\delta$ phases; this condition leads to a constant thermal expansion coefficient between $1,000{ }^{\circ} \mathrm{C}$ and $1,180{ }^{\circ} \mathrm{C}$. However, whether the measured thermal expansion coefficient of 9Cr-ODS ferritic steel with $0.35 \mathrm{Y}_{2} \mathrm{O}_{3}$ corresponded to the broken straight line (residual ferrite) or the broken thin curve ( $\delta$-ferrite) is not obvious from only the thermal expansion coefficient data shown in Fig. 5.

\section{Discussion}

Alinger et al. have carried out a small angle neutron scattering (SANS) experiment for a U14YWT specimen ( $\left.\mathrm{Fe}-14 \mathrm{Cr}-0.4 \mathrm{Ti}-3 \mathrm{~W}-0.25 \mathrm{Y}_{2} \mathrm{O}_{3}\right)$. The neutron scattering cross section $(\mathrm{d} \Sigma / \mathrm{d} \Omega)$ and scattering vector $\left(\mathrm{q}^{2}\right)$ were measured for the MAed powder after hot-isostatic-pressing (HIP) or thermal annealing at $700{ }^{\circ} \mathrm{C}, 850{ }^{\circ} \mathrm{C}, 1000{ }^{\circ} \mathrm{C}$, and $1150{ }^{\circ} \mathrm{C}[18]$. Their results indicate that the MAed powder annealed at $700{ }^{\circ} \mathrm{C}$ shows the smallest radius and highest density for the $\mathrm{Y}-\mathrm{Ti}$ complex oxide particles. Assuming that the $\mathrm{Y}_{2} \mathrm{O}_{3}$ particles were decomposed during mechanical alloying [18, 19], the subsequent annealing resulted in the formation and precipitation of $\mathrm{Y}-\mathrm{Ti}$ complex oxide particles at elevated temperatures of $700{ }^{\circ} \mathrm{C}$ or higher. Since the 
reverse transformation of the ferrite $\delta$-phase to the austenite $\gamma$-phase took place at the elevated temperature of over $850{ }^{\circ} \mathrm{C}$, which is higher than the precipitation temperature of the Y-Ti complex oxide particles, it is possible to consider that the partial retention of the residual $\alpha$-ferrite can be attributed to the presence of the $\mathrm{Y}-\mathrm{Ti}$ complex oxide particles in the 9Cr-ODS ferritic steels; these particles should block the motion of the $\alpha-\gamma$ interface [20], thereby partly suppressing the reverse transformation of the $\alpha$-phase to the $\gamma$-phase. In this section, we present more quantitative evaluation.

The chemical driving force $(\Delta \mathrm{G})$ for the reverse transformation of the $\alpha$-phase to the $\gamma$-phase in the $\mathrm{Fe}-0.13 \mathrm{C}-2 \mathrm{~W}-0.2 \mathrm{Ti}$ system without $\mathrm{Y}_{2} \mathrm{O}_{3}$ can be evaluated in terms of Gibbs energy vs. carbon content curves at each temperature; these curves were derived by using the Thermo-Calc code and TCFE6 database. The result of the calculation is presented in Fig. 7. $\Delta \mathrm{G}$ corresponds to the Gibbs energy difference in the $\gamma$-phase and the $\alpha$-phase, where a positive value of the driving force, i.e., $\Delta \mathrm{G}>0$, indicates the complete transformation to the single $\gamma$-phase, while a zero value, i.e., $\Delta \mathrm{G}$ $=0$, represents the equilibrium between the $\alpha$-phase and the $\gamma$-phase at low temperatures and between the $\gamma$-phase and the $\delta$-phase at high temperatures above $1180{ }^{\circ} \mathrm{C}$. The peak value of the driving force for the reverse transformation of the $\alpha$-phase to the $\gamma$-phase reaches $4 \mathrm{MJ} \mathrm{m}^{-3}$ at $1000^{\circ} \mathrm{C}$.

The pinning force (F) against the motion of the $\alpha / \gamma$ interface can be expressed as equation (2), which was obtained from the modified Zener equation by Mishizawa et al. [21].

$$
\mathrm{F}=\frac{3}{8} \frac{\sigma \cdot \mathrm{f}_{\mathrm{p}}^{2 / 3}}{\mathrm{r}},
$$

where $\sigma\left(\mathrm{J} / \mathrm{m}^{2}\right)$ is the interfacial energy between $\alpha$ and $\gamma$ and its value was selected to 
be $0.56 \mathrm{~J} / \mathrm{m}^{2}$ [22]. $\quad \mathrm{r}(\mathrm{m})$ is the radius of the oxide particles in the $\alpha$-phase. The chemical form of the oxide particles was determined to be $\mathrm{Y}_{2} \mathrm{Ti}_{2} \mathrm{O}_{7}$ by TEM[1], and their diameter was estimated to be about $3 \mathrm{~nm}$ in the specimen of the same composition by authors[11][14]. Thus, $r$ was set as $1.5 \mathrm{~nm} . \quad \mathrm{f}_{\mathrm{p}}$ is the volume fraction of dispersed oxide particles (-), and it was derived on the basis of the experimental evidence that oxide particles consist of $\mathrm{Y}_{2} \mathrm{Ti}_{2} \mathrm{O}_{7}$. By substituting these values into equation (2), we determined the value of the pinning force $F$ for 0.1 mass\%, 0.35 mass\%, and 0.7 mass $\% \mathrm{Y}_{2} \mathrm{O}_{3}$, which are shown in Fig. 7. The value of F increases with the amount of $\mathrm{Y}_{2} \mathrm{O}_{3}$ added according to the relation of $f^{2 / 3}$.

The velocity of the $\alpha-\gamma$ interface motion (v) is proportional to the difference between $\mathrm{F}$ and $\Delta \mathrm{G}$, as shown in equation (3):

$\mathrm{v}=\mathrm{M} \times(\Delta \mathrm{G}-\mathrm{F})$.

$\mathrm{M}$ is the mobility of the interface. $\Delta \mathrm{G}$ and $\mathrm{F}$ are competitive, and $\Delta \mathrm{G}>\mathrm{F}$ indicates a positive velocity for the interface motion, i.e., the reverse transformation of the $\alpha$-phase to the $\gamma$-phase. On the other hand, $\Delta \mathrm{G}<\mathrm{F}$ indicated that the $\alpha-\gamma$ interface could be pinned by oxide particles, and thus the $\alpha$-phase was retained. The results of calculation shown in Fig. 7 reveal that in the case of $\mathrm{Y}_{2} \mathrm{O}_{3}$ contents of 0.35 mass\% and 0.7 mass\%, the pinning force is larger than the driving force, which is reasonably consistent with the experimental observation of retaining the residual $\alpha$-ferrite at the $\alpha / \gamma$ reverse transformation.

On the basis of the above discussion, the process of the formation of the residual $\alpha$-ferrite is schematically represented in Fig. 8. In the case of the Fe-Cr-0.13C-2W-0.2Ti system without $\mathrm{Y}_{2} \mathrm{O}_{3}$, the $\gamma$-phase exhibited nucleation and 
growth at $\mathrm{A}_{\mathrm{C} 1}$ point $\left(850^{\circ} \mathrm{C}\right.$, from Fig. 4) and the reverse transformation of the $\alpha$-phase to the $\gamma$-phase could be completed at the $\mathrm{A}_{\mathrm{C} 3}$ point $\left(880^{\circ} \mathrm{C}\right.$, from Fig. 4). In contrast, for the specimens with 0.35 mass $\%$ and 0.7 mass $\% \mathrm{Y}_{2} \mathrm{O}_{3}$, the velocity of the $\alpha-\gamma$ interface motion is markedly reduced because of the dragging by the oxide particles, and this reduction in the velocity leads to the retention of the $A_{C 3}$ point. It is considered that some of the $\alpha$-ferrite remains in the $\gamma$-phase at a temperature above the $\mathrm{A}_{\mathrm{C} 3}$ point.

\section{Conclusion}

The origin and formation process of the ferrite phase in 9Cr-ODS ferritic steels were investigated by SEM observation, high-temperature X-ray diffraction analysis, and the dilatometric measurement of the MAed powders that were milled by a planetary-type ball. Thermodynamic analyses were also carried out. The results obtained in this study can be summarized as follows:

(1) An addition of 0.35 mass $\%$ and 0.7 mass $\% \mathrm{Y}_{2} \mathrm{O}_{3}$ to 9Cr-ODS ferritic steels induced the retention of the ferrite phase at the normalizing heat-treatment, whereas the addition of 0 mass $\%$ and 0.1 mass $\% \mathrm{Y}_{2} \mathrm{O}_{3}$ led to the full martensite structure without the ferrite phase. The normalizing was conducted at the elevated temperature of $1050{ }^{\circ} \mathrm{C}$ for $1 \mathrm{~h}$. This finding indicates that the $\alpha-\gamma$ reverse transformation could be partly suppressed rather than delayed by $\mathrm{Y}-\mathrm{Ti}$ complex oxide particles in the 9Cr-ODS ferritic steels,

(2) Quantitative analyses performed using the Thermo-Calc code and TCFE6 database also indicated the possibility for the retention of the residual $\alpha$-ferrite because of 
the pinning of the $\alpha-\gamma$ interface motion by the dispersed $\mathrm{Y}-\mathrm{Ti}$ complex oxide particles at the $\mathrm{A}_{\mathrm{C} 3}$ point.

(3) Therefore, it is considered that the ferrite phase is not a $\delta$-phase in equilibrium with the $\gamma$-phase at $1050{ }^{\circ} \mathrm{C}$ in $\mathrm{Fe}-9 \mathrm{Cr}-0.13 \mathrm{C}-2 \mathrm{~W}-0.2 \mathrm{Ti}-0.35 \mathrm{Y}_{2} \mathrm{O}_{3}$, but this ferrite can be retained by the un-transforming to the austenite $\gamma$-phase at the $\mathrm{A}_{\mathrm{C} 3}$ point.

\section{Acknowledgments}

We would like to thank Prof. R. O. Suzuki of Hokkaido University for his cooperation with the high-temperature X-ray diffraction analyses; we also thank Associate Prof. S. Miura and Mr. K. Ohkubo of Hokkaido University for their cooperation with the dilatometric measurement.

\section{References}

[1] G.R. Odette, M.J. Alinger and B.D. Wirth, Annu. Rev. Mater. Res. 38 (2008) 471-503.

[2] S. Ukai and M. Fujiwara, J. Nucl. Mater. 307-311 (2002) 749-757.

[3] T.R. Allen, Workshop on Higher Temperature Materials for Advanced Nuclear Energy Systems, DOE Office of Nuclear Energy, Science and Technology, La Jolla, CA, March 18 (2002).

[4] S. Ukai, T. Nishida, T. Okuda and T. Yoshitake, J. Nucl. Sci. Technol. 35, 4 (1998) 294-300.

[5] S. Ukai, T. Nishida, T. Okuda and T. Yoshitake, J. Nucl. Mater. 258-263 (1998) 1745-1749.

[6] S. Ukai, S. Mizuta, M. Fujiwara, T. Okuda and T. Kobayashi, J. Nucl. Sci. Technol. 
39, 7 (2002) 778-788.

[7] S. Ukai, S. Mizuta, M. Fujiwara, T. Okuda and T. Kobayashi, J. Nucl. Mater. 307-311 (2002) 758-762.

[8] S. Ukai, T. Kaito, S. Otsuka, T. Narita, M. Fujiwara and T. Kobayashi, ISIJ International 43, 12 (2003) 2038-2045.

[9] S. Ukai, T. Narita, A. Alamo and P. Pamentier, J. Nucl. Mater. 329-333 (2004) $356-361$.

[10] Phase Transformations in Metals and Alloys: D. P. Porter and K. E. Easterling, Second Edition, Taylor and Francis, 1992.

[11] S. Ohtuska, S. Ukai, M. Fujiwara, T. Kaito and T. Narita, Materials Transaction, 46, 3 (2005) 487-492.

[12] S. Ohtsuka, S. Ukai, M. Fujiwara, H. Sakasegawa, T. Kaito and T. Narita, J. Nucl. Mater. 367-370 (2007) 160-165.

[13] S. Ohtsuka, S. Ukai, M. Fujiwara, T. Kaito and T Narita, J. Phys. Chem. Solids. 66 (2005) 571-575.

[14] S. Ohtsuka, S. Ukai, M. Fujiwara, T. Kaito and T. Narita, J. Nucl. Mater. 329-333 (2004) 372-376.

[15] S. Ohtsuka, S. Ukai and M. Fujiwara, J. Nucl. Mater. 351 (2006) 241-246.

[16] C. Cayron, E. Rath, I. Chu and S. Kaunois, J. Nucl. Mater. 335 (2004) 83-102.

[17] Creep-resistant Steels: Edited by F. Abe, T. U. Kern and R. Viswanathan, Woodhead Publishing Limited, 2008

[18] M.J. Alinger, G.R. Oddett and D.T. Hoelzer, J. Nucl. Mater. 329-333 (2004) 382-386. 
[19] T. Okuda and M. Fujiwara, J. Mater. Sci. Lett. 14 (1995) 1600.

[20] S. Ukai and S. Ohtsuka, Energy Materials, 2, 1, (2007) 26-35.

[21] T. Nishizawa, I. Ohnuma and K. Ishida, Materials Transaction, Vol.38, No.11 (1997) 950-956.

[22] J.W. Martion and R.D. Doherty, Stability of Microstructure in Metallic Systems, Cambridge University Press, Cambridge, 1976, 173. 
Figure Captions

Fig.1 Computed phase diagram with respect to carbon content for $\mathrm{Fe}-9 \mathrm{Cr}-\mathrm{xC}-0.2 \mathrm{Ti}-2 \mathrm{~W}$ system without $\mathrm{Y}_{2} \mathrm{O}_{3}$.

Fig.2 SEM photographs of the MAed powders for 0 mass $\%, 0.1$ mass $\%, 0.35$ mass $\%$ and 0.7 mass $\% \mathrm{Y}_{2} \mathrm{O}_{3}$ specimens after normalizing at $1050{ }^{\circ} \mathrm{C}$ and subsequently quenched to water.

Fig.3 Results of X-ray diffraction measurement at $950{ }^{\circ} \mathrm{C}$ for 0 mass $\%, 0.35$ mass $\%$, and 0.7 mass $\% \mathrm{Y}_{2} \mathrm{O}_{3}$ specimens.

Fig.4 Results of thermal expansion measurement between $700{ }^{\circ} \mathrm{C}$ and $1100{ }^{\circ} \mathrm{C}$ at temperature rising of $0.33{ }^{\circ} \mathrm{C} / \mathrm{s}$ for 0 mass $\%$ and 0.35 mass $\% \mathrm{Y}_{2} \mathrm{O}_{3}$ specimens.

Fig.5 Estimated thermal expansion coefficients between $1000{ }^{\circ} \mathrm{C}$ and $1200{ }^{\circ} \mathrm{C}$ at temperature rising of $0.33{ }^{\circ} \mathrm{C} / \mathrm{s}$ for 0 mass $\%$ and 0.35 mass $\% \mathrm{Y}_{2} \mathrm{O}_{3}$ specimens. The broken straight line shows the $\alpha_{\text {ODS }}$, assuming that volume of ferrite phase is constant at this temperature range. The broken fine curve was estimated on the assumption that the $\delta$-phase is in equilibrium with $\gamma$-phase and its volume fraction increases with rising temperature, as illustrated in Fig.6.

Fig.6 Lever rule showing the volume fraction between $\delta$-ferrite $\left(\mathrm{F}_{\delta}\right)$ and $\gamma$-austenite $\left(\mathrm{F}_{\gamma}\right)$ at the temperature between $1,000{ }^{\circ} \mathrm{C}$ and $1,200{ }^{\circ} \mathrm{C}$.

Fig.7 Comparison of the driving force for $\alpha$ to $\gamma$ reverse transformation derived by using Thermo-Calc code and pinning force due to oxide particles derived according to Equation (2) for 0.1 mass\%, 0.35 mass\% and 0.7 mass\% $\mathrm{Y}_{2} \mathrm{O}_{3}$ 
specimens.

Fig.8 Schematic representation of the residual $\alpha$-ferrite formation in 9Cr-ODS ferritic steel. 


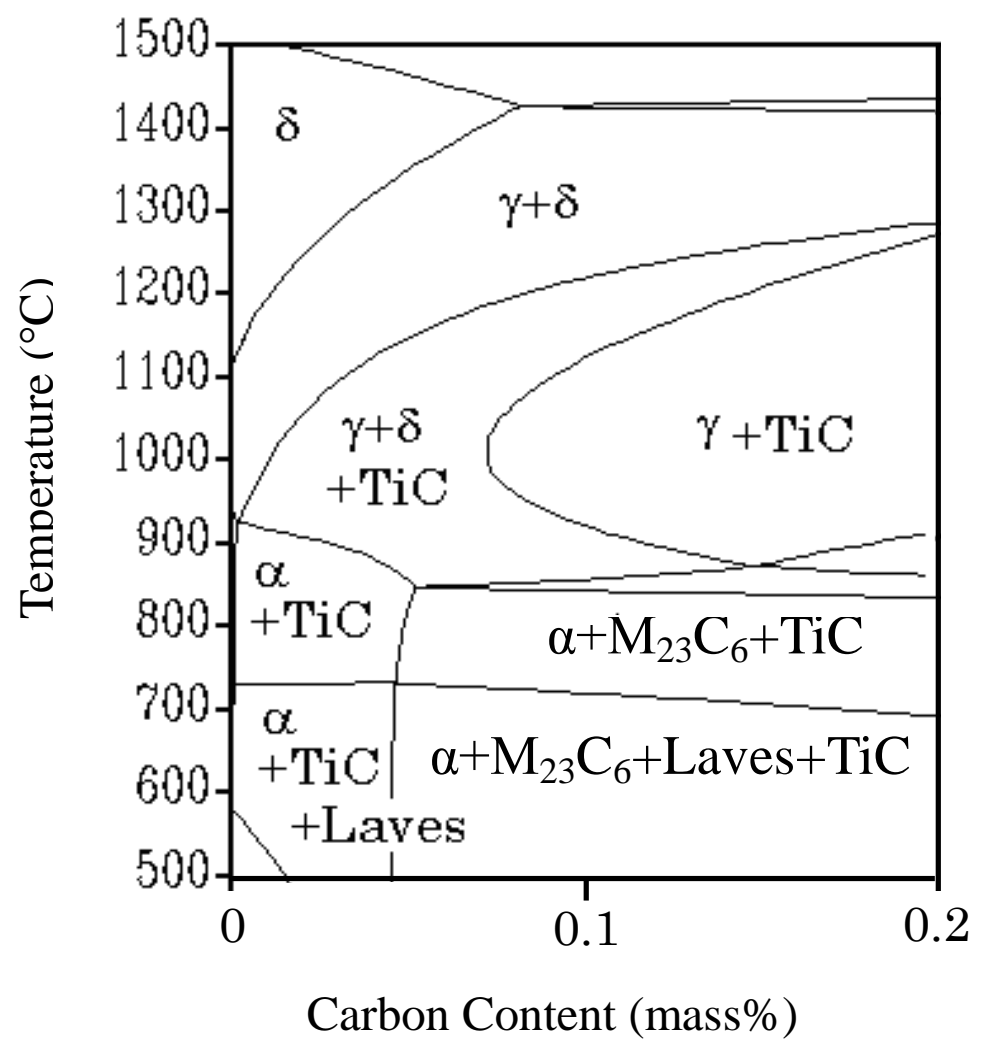

Fig.1 Computed phase diagram with respect to carbon content for $\mathrm{Fe}-9 \mathrm{Cr}-\mathrm{xC}-0.2 \mathrm{Ti}-2 \mathrm{~W}$ system without $\mathrm{Y}_{2} \mathrm{O}_{3}$. 


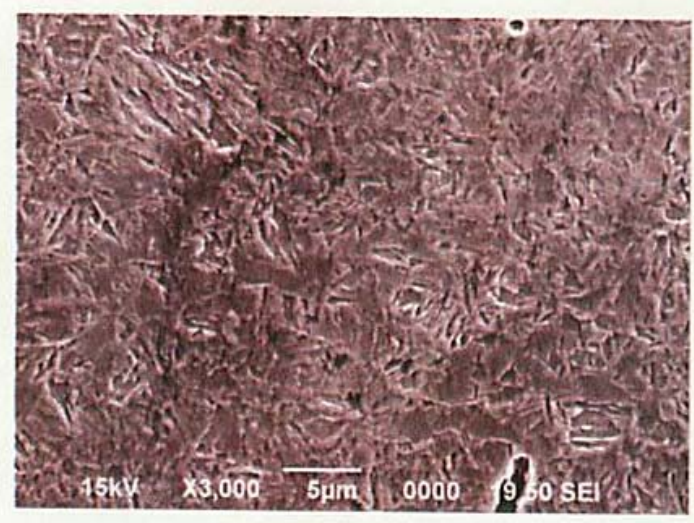

without $\mathrm{Y}_{2} \mathrm{O}_{3}$

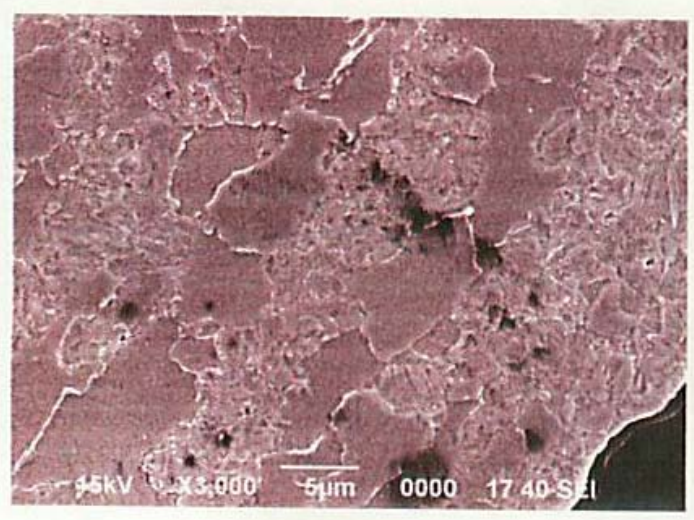

0.35 mass $\% \mathrm{Y}_{2} \mathrm{O}_{3}$

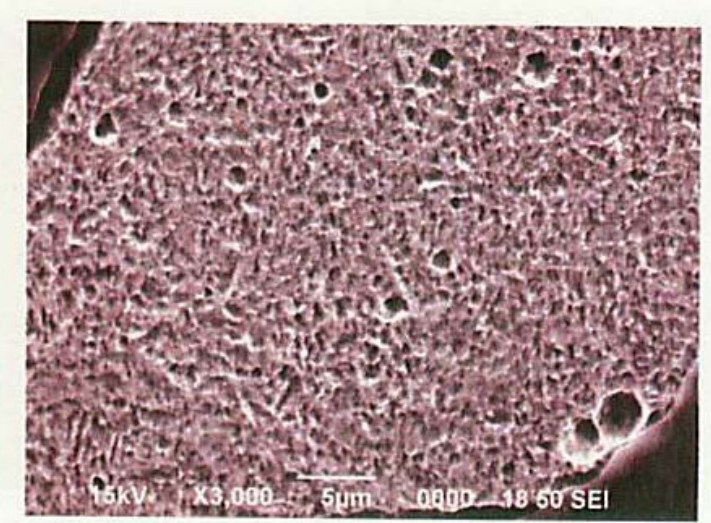

0.1 mass $\% \mathrm{Y}_{2} \mathrm{O}_{3}$

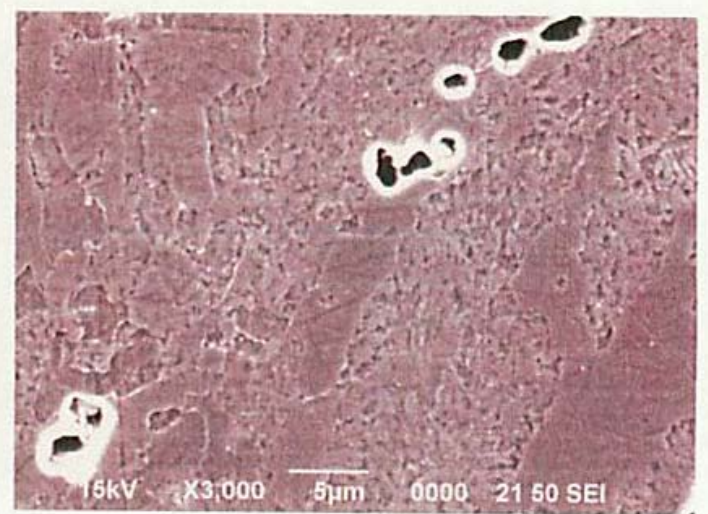

0.7 mass $\% \mathrm{Y}_{2} \mathrm{O}_{3}$

Fig.2 SEM photographs of the MAed powders for 0 mass\%, 0.1 mass\%, 0.35 mass\% and 0.7 mass $\% \mathrm{Y}_{2} \mathrm{O}_{3}$ specimens after normalizing at $1050{ }^{\circ} \mathrm{C}$ and subsequently quenched to water. 


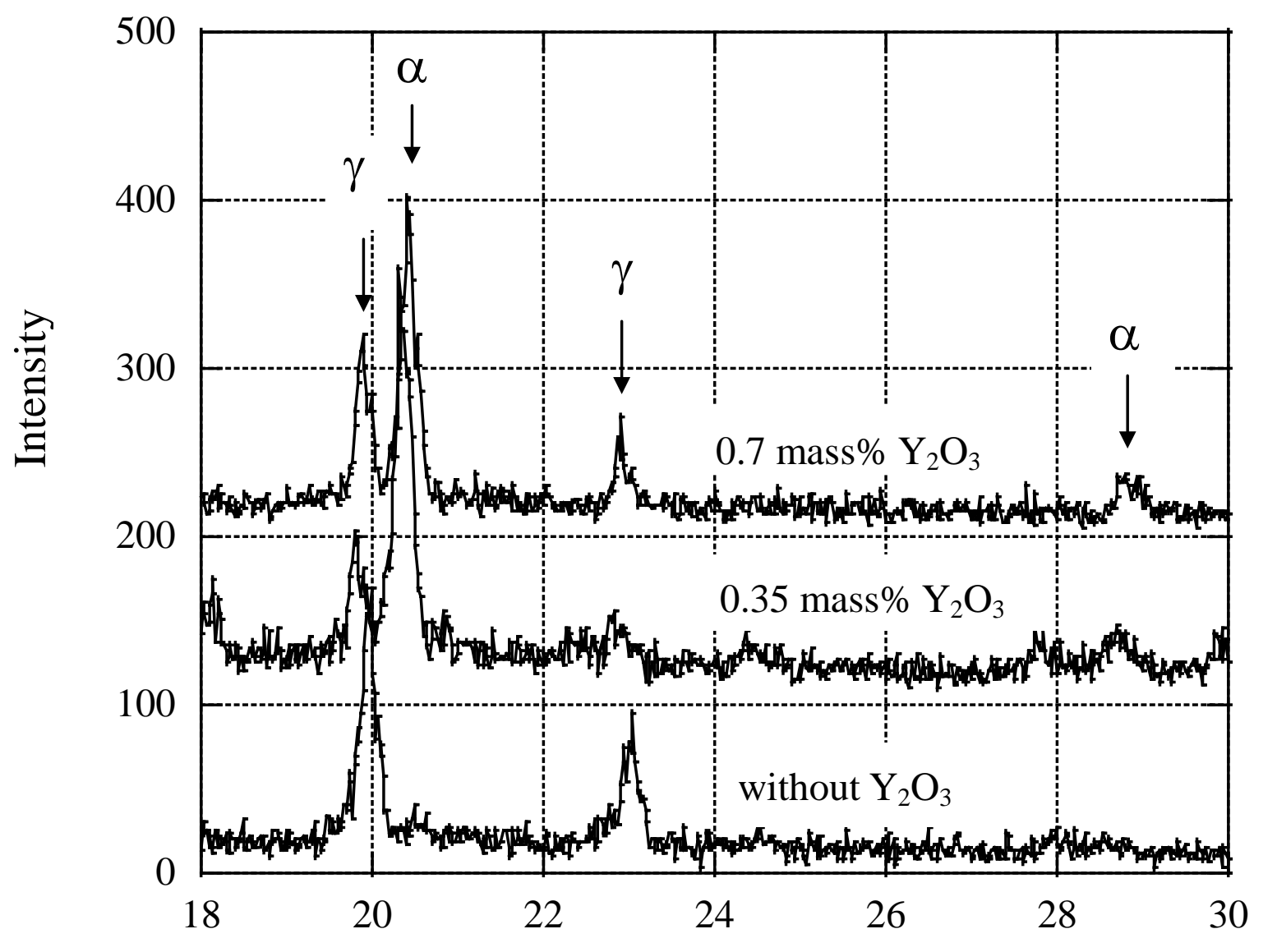

\section{$2 \theta$}

Fig.3 Results of X-ray diffraction measurement at $950{ }^{\circ} \mathrm{C}$ for 0 mass\%, 0.35 mass $\%$, and 0.7 mass $\% \mathrm{Y}_{2} \mathrm{O}_{3}$ specimens. 


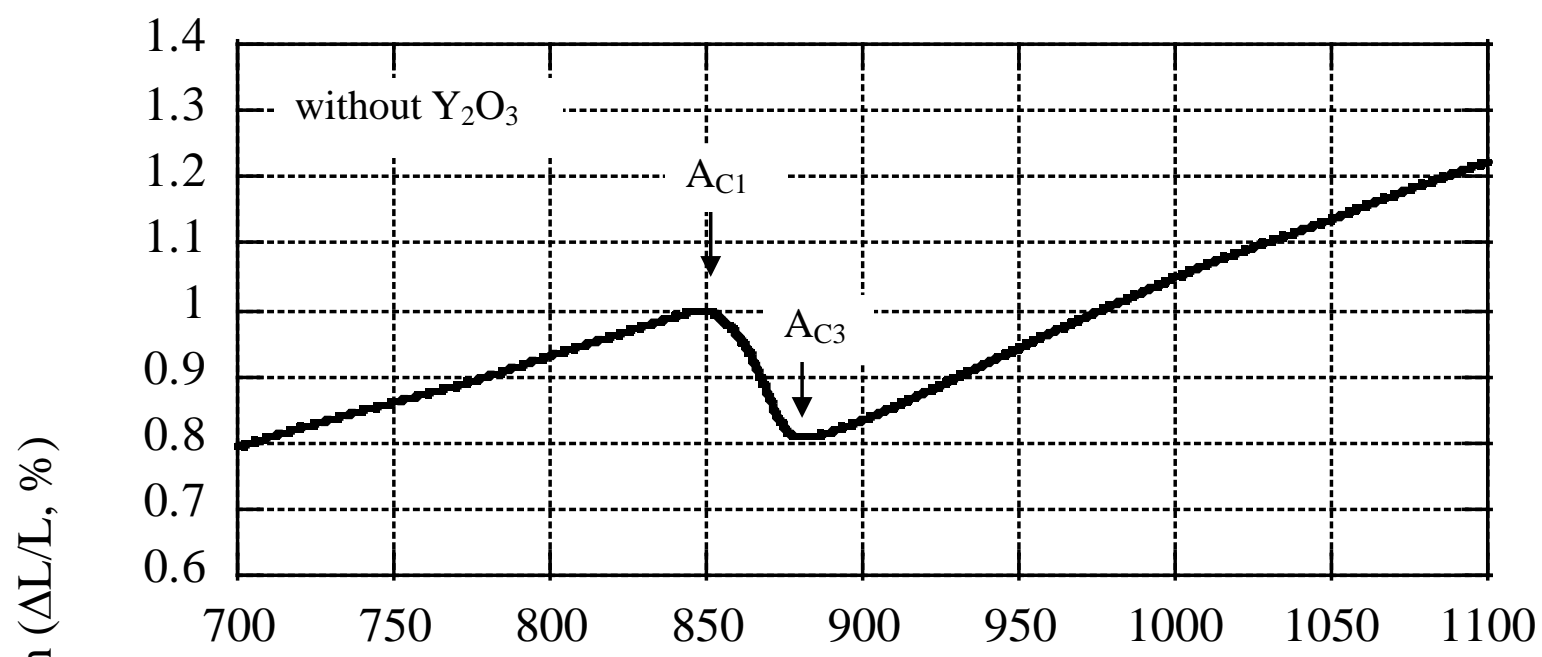

옴

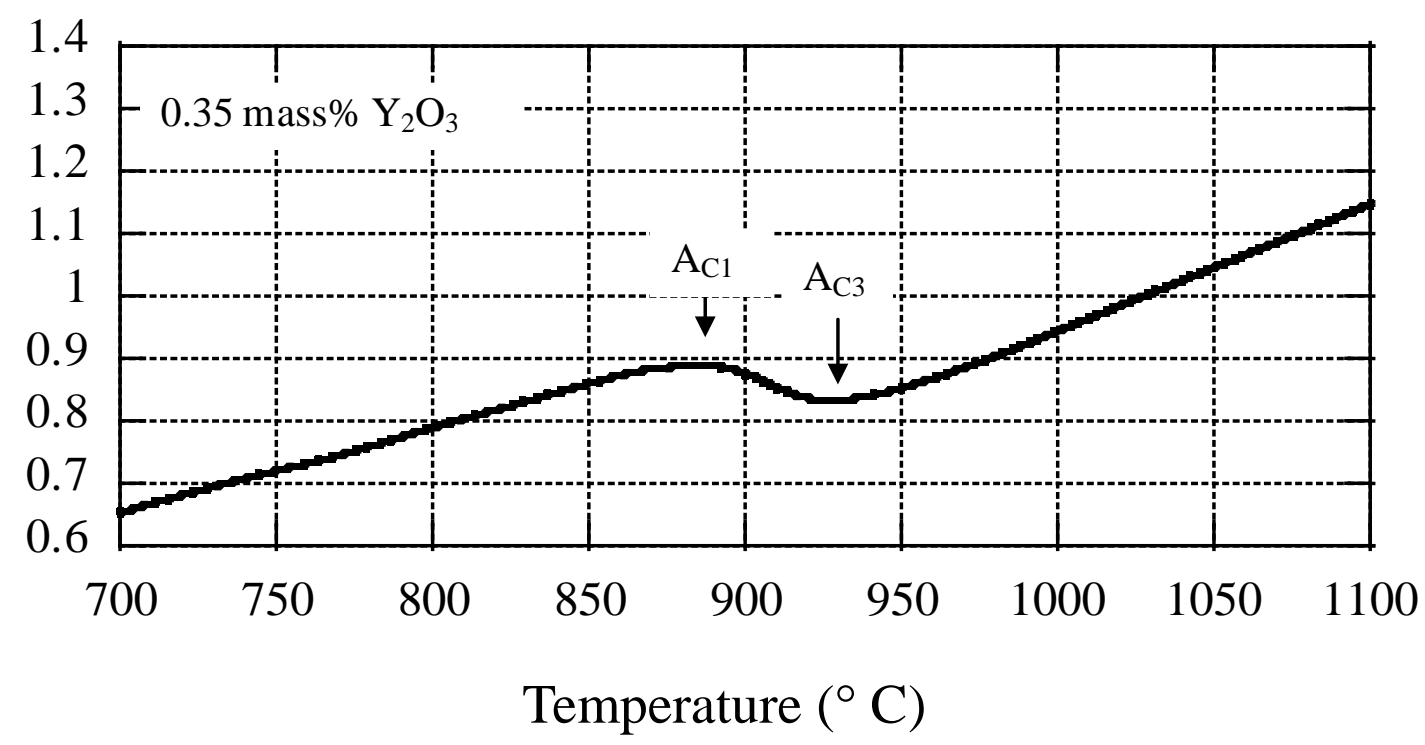

Fig.4 Results of thermal expansion measurement between $700{ }^{\circ} \mathrm{C}$ and $1100{ }^{\circ} \mathrm{C}$ at temperature rising of $0.33{ }^{\circ} \mathrm{C} / \mathrm{s}$ for 0 mass\% and 0.35 mass $\% \mathrm{Y}_{2} \mathrm{O}_{3}$ specimens. 


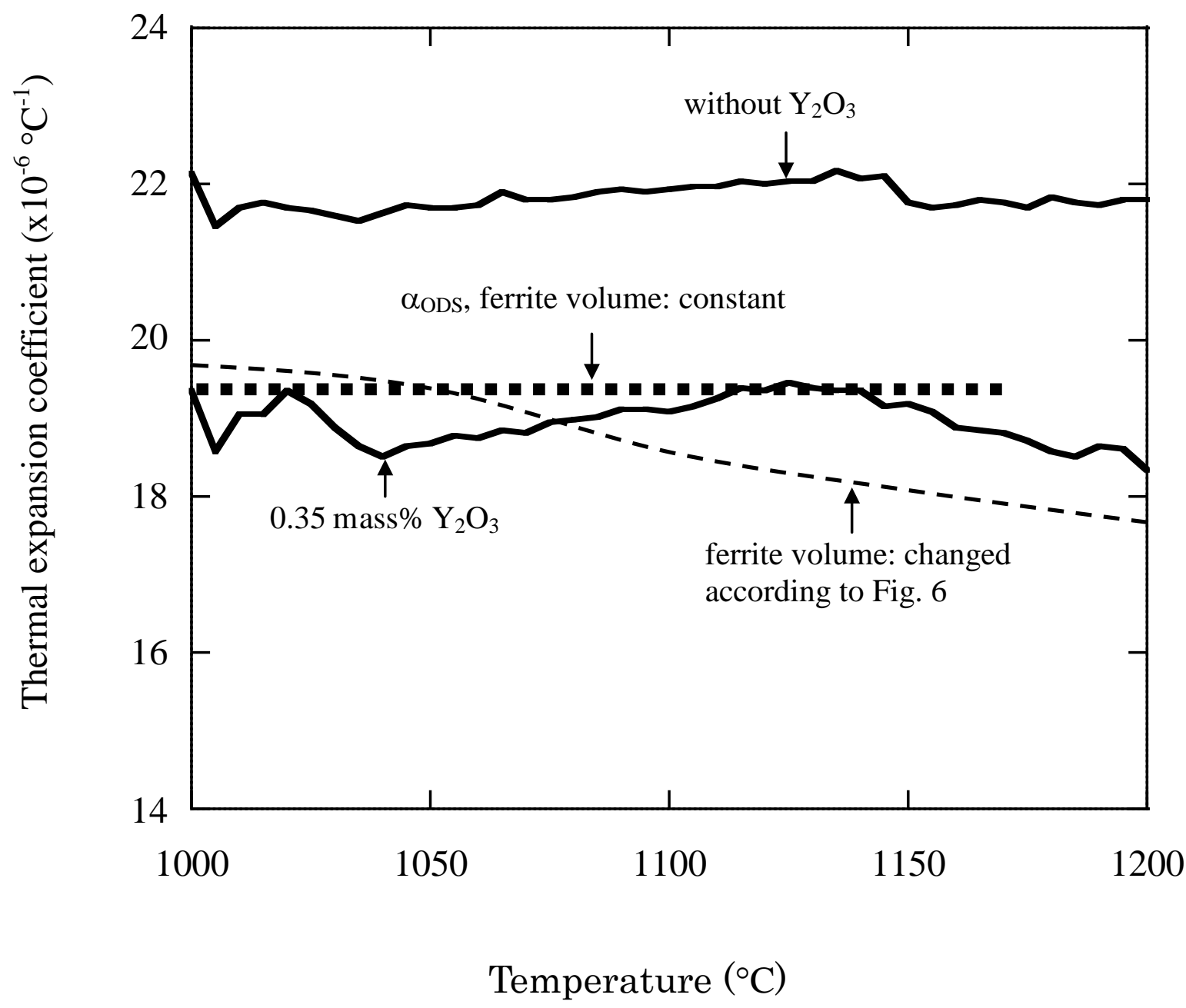

Fig.5 Estimated thermal expansion coefficients between $1000{ }^{\circ} \mathrm{C}$ and $1200{ }^{\circ} \mathrm{C}$ at temperature rising of $0.33{ }^{\circ} \mathrm{C} / \mathrm{s}$ for 0 mass\% and 0.35 mass $\% \mathrm{Y}_{2} \mathrm{O}_{3}$ specimens. The broken straight line shows the $\alpha_{\mathrm{ODS}}$, assuming that volume of ferrite phase is constant at this temperature range. The broken fine curve was estimated on the assumption that the $\delta$-phase is in equilibrium with $\gamma$-phase and its volume fraction increases with rising temperature, as illustrated in Fig.6. 


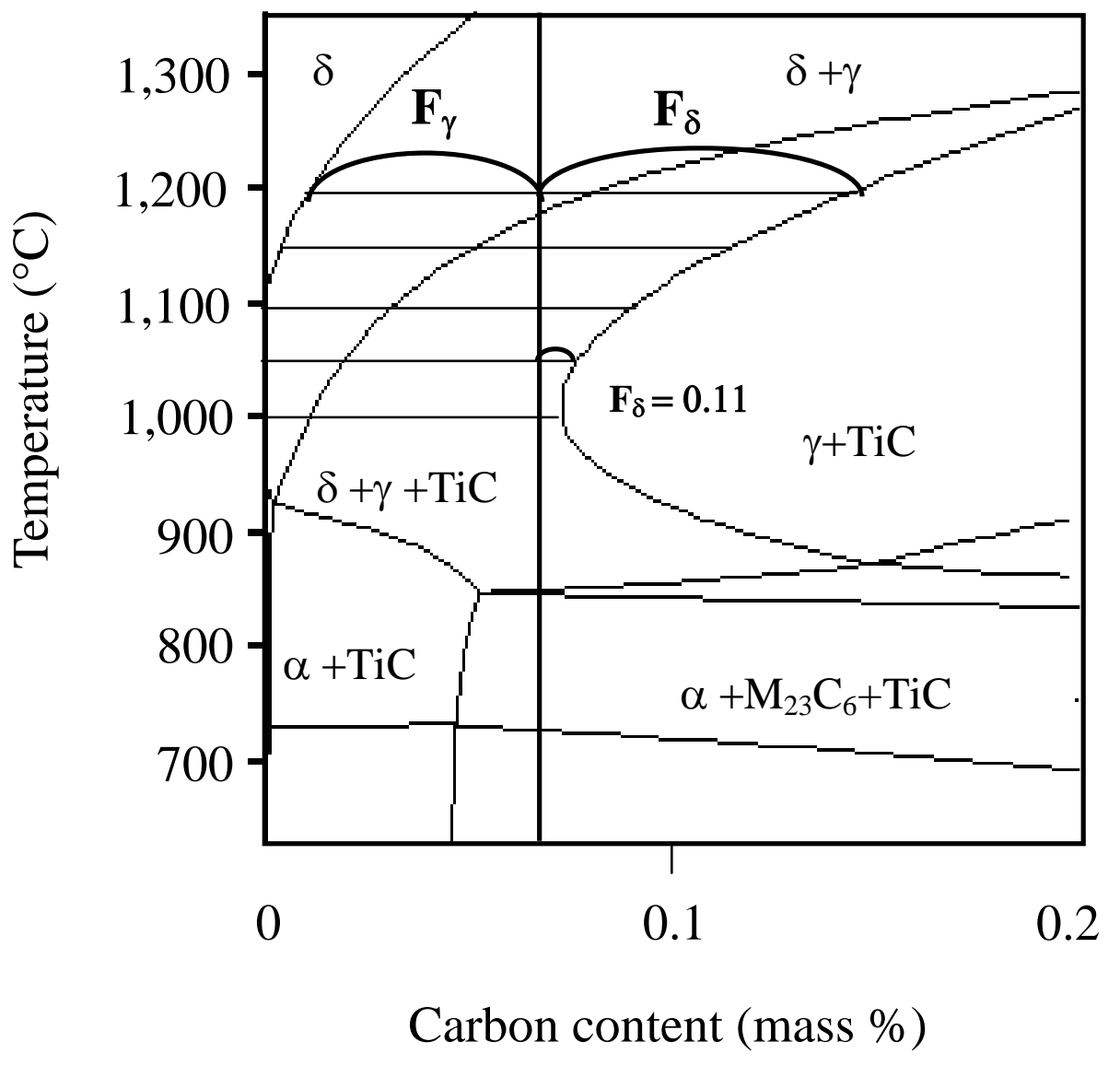

Fig.6 Lever rule showing the volume fraction between $\delta$-ferrite $\left(\mathrm{F}_{\delta}\right)$ and $\gamma$-austenite $\left(\mathrm{F}_{\gamma}\right)$ at the temperature between $1,000{ }^{\circ} \mathrm{C}$ and $1,200{ }^{\circ} \mathrm{C}$. 


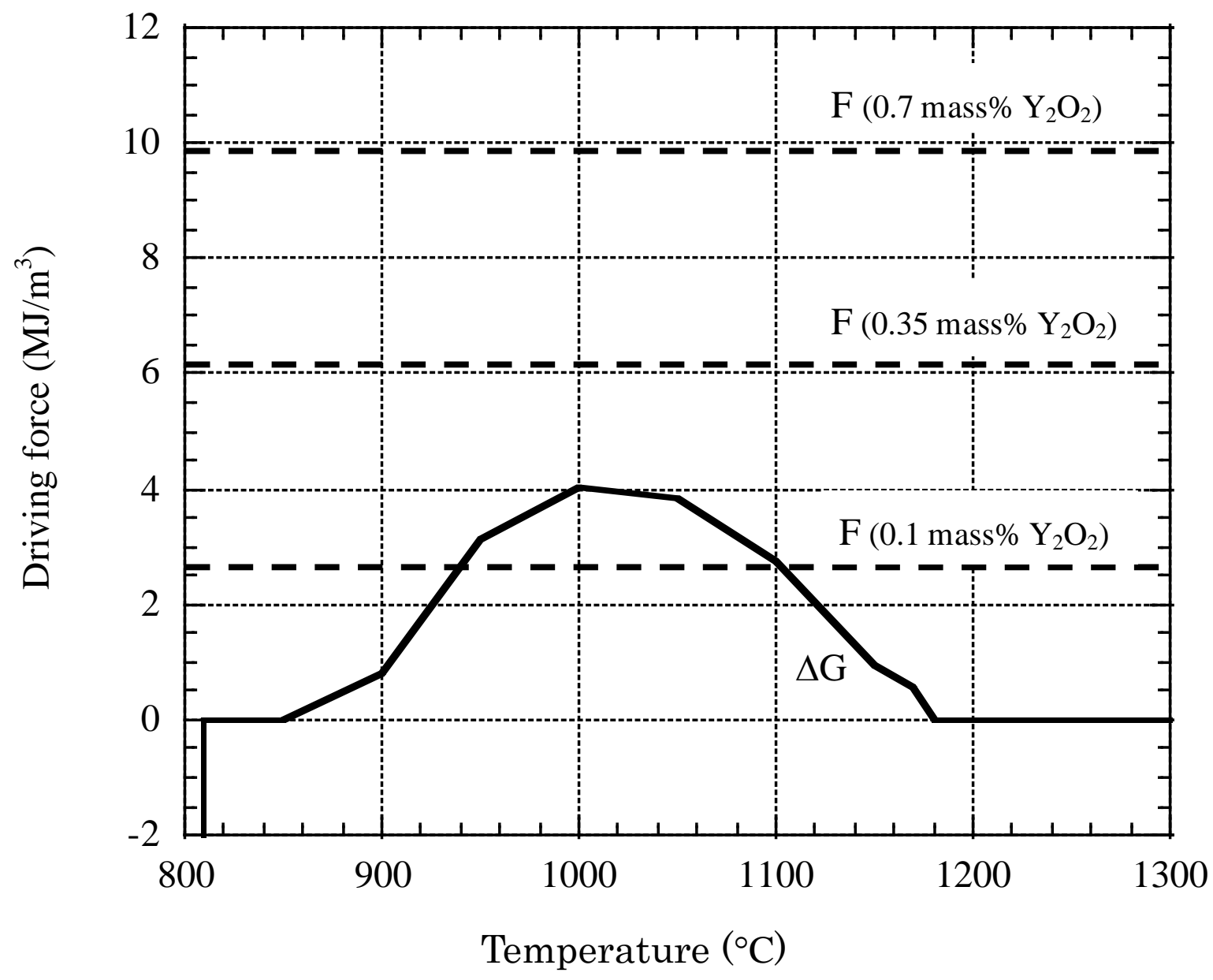

Fig.7 Comparison of the driving force for $\alpha$ to $\gamma$ reverse transformation derived by using Thermo-Calc code and pinning force due to oxide particles derived according to Equation (2) for 0.1 mass\%, 0.35 mass\% and 0.7 mass\% $\mathrm{Y}_{2} \mathrm{O}_{3}$ specimens. 
without $\mathrm{Y}_{2} \mathrm{O}_{3}$
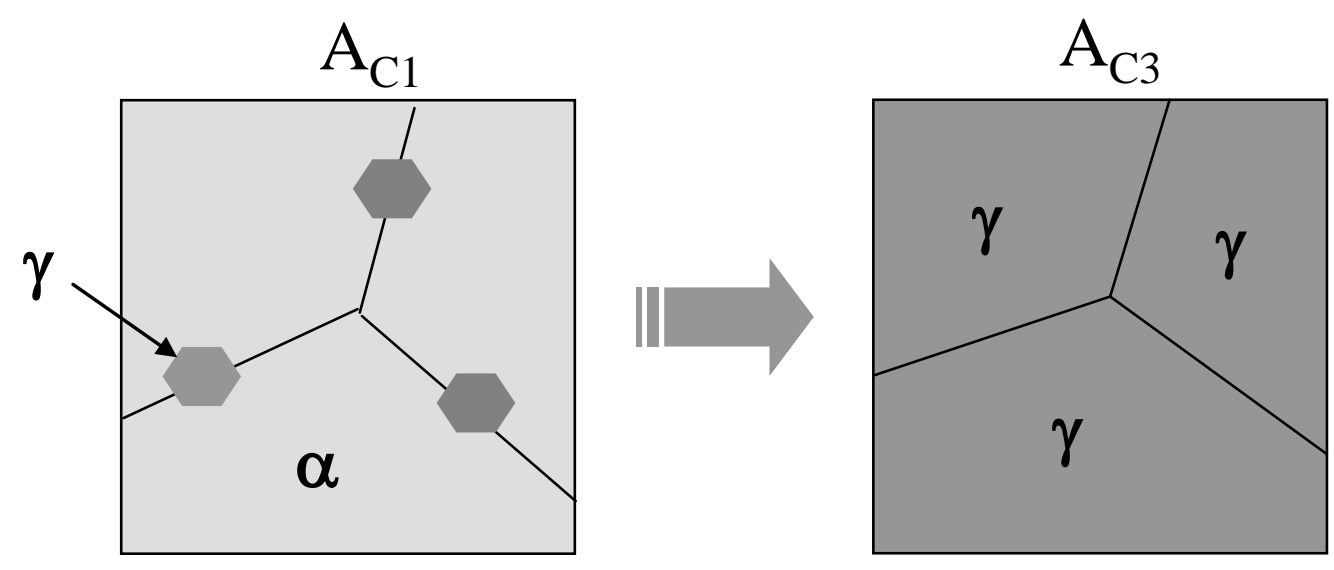

0.35 mass $\% \mathrm{Y}_{2} \mathrm{O}_{3}$
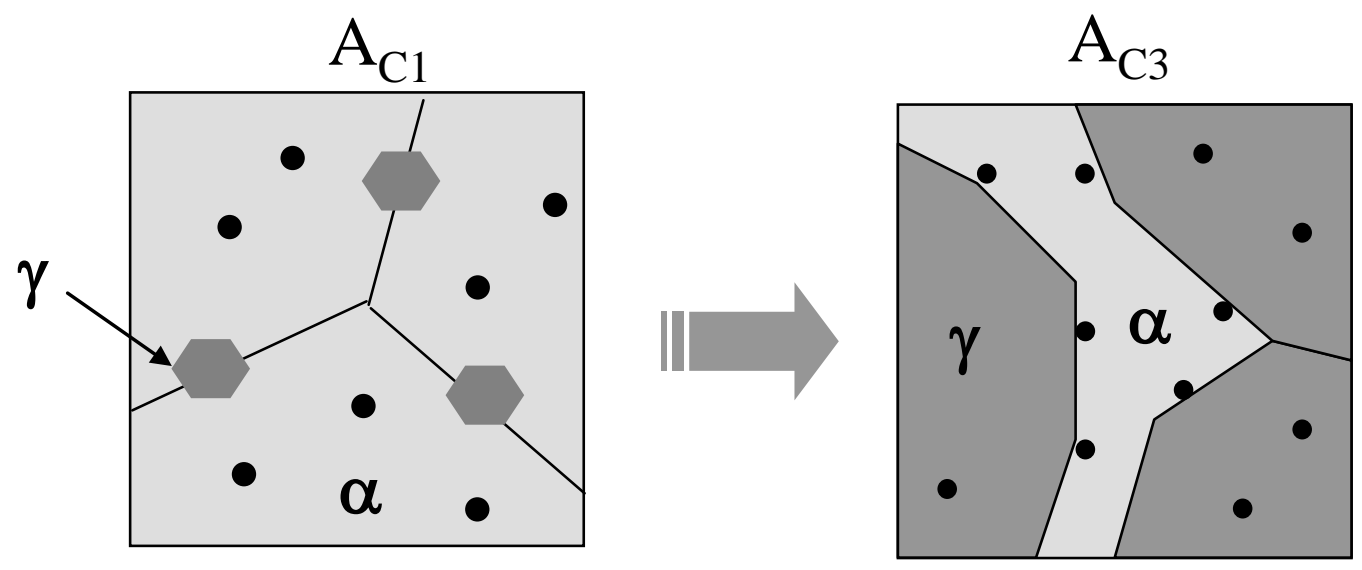

Fig.8 Schematic representation of the residual $\alpha$-ferrite formation in 9Cr-ODS ferritic steel. 